\title{
Výstupy či procesy: paradigmatický (kvazi)spor environmentální výchovy
}

\section{Jan Činčera}

\section{Envigogika 2009/IV/2 - Recenzované články/ Reviewed Papers}

Publikováno/Published 30. 09. 2009

DOI: http://dx.doi.org/10.14712/18023061.38

\begin{abstract}
Abstrakt:
Článek prezentuje rozdíly mezi výstupově a procesně orientovanými paradigmatickými modely environmentální výchovy. Stručně popisuje jejich historii a hlavní teze. Autor předpokládá, že deklarované rozdíly souvisí s určitým neporozuměním modelu odpovědného environmentálního chování, který představuje klíčovou teorii výstupově orientovanému př́stupu. Domnívá se, že v praxi nejsou prezentované rozdíly tak zásadní a že platnost každého nového př́stupu by měla být doložena evaluací jeho dopadů na znalosti, dovednosti, postoje, hodnoty a chování.
\end{abstract}

\section{Klíčová slova:}

Odpovědné environmentální chování, procesně orientovaná výchova, výstupově orientovaná výchova

\begin{abstract}
:
The article presents differences between outcome-based and process-based paradigmatic approaches in environmental education. It briefly summarises their history and main points. The author presupposes that the controversy lies partially in a misunderstanding of the model of responsible environmental behavior, which is crucial for an outcome-based approach. He argues that the differences between paradigms are not so deep in praxis and that all new approaches should be evaluated in terms of their contribution to knowledge, skills, values, attitudes and behavior.
\end{abstract}

\section{Key words:} education

Responsible environmental behavior, process-based education, outcome-based 


\section{Úvod}

Jana Dlouhá (2009a, b) v posledním čísle Envigogiky otevřela důležité téma environmentální výchovy, totiž diskusi o jejím základním paradigmatu. Podle jejího názoru nelze jako cíl environmentální výchovy označit proenvironmentální chování, ale spíše určité kvality, respektive kompetence žáků. Envigogika se tak zapojuje do diskuse, která na stránkách zahraničních oborových časopisů probíhá již nejméně dvanáct let.

Protože je těžké k tématu tak diskutovanému přidat mnoho vlastního, pokusím se v následujícím textu nejprve shrnout průběh a širší souvislosti celé diskuse. Ve druhé části budu reagovat na myšlenky uvedené v textech Jany Dlouhé.

\section{Výstupově a procesně orientované přístupy v environmentální výchově}

\section{Předreflektivní období}

Přestože první použití pojmu environmentální výchova se datuje už od čtyřicátých let, leží skutečné počátky oboru až v šedesátých letech dvacátého století. Environmentální výchova $v$ této době navazuje na tradice prírodních studií (nature study), výchovy v prírodě (outdoor education) a výchově k ochraně přírody (conservation education), ke kterým se $v$ sedmdesátých letech připojily vlivy některých dalších směrů (např. progresivistické výchovy, výchovy k využívání zdrojů, výchovy o populaci a dalších). Prvním oborovým časopisem se stává Environmental education (později The Journal of Environmental Education), založený v roce 1969, v roce 1971 je založena první profesní asociace (Disinger, 2005).

Jednu z prvních definic formuluje William Stapp v roce 1969. Podle něj je cílem environmentální výchovy "vychovávat občana, který se vědomě zajímá o biofyzikální životní prostředí a jeho problémy, ví, jak tyto problémy řešit a je motivován $k$ tomu se do jejich řešení zapojit" (Stapp, 2005). V dalším procesu hledání vhodné definice se jako hlavní cíl objevila „kvalita života" (Roth, podle Disinger, 2005) či „environmentální gramotnost". Disinger a Roth rozlišili tři úrovně environmentální gramotnosti (Disinger, 1997; Morrone, Mancl \& Carr, 2001; Moseley, 2000; Wright, 2008; Negev et. al., 2008): nominální, jako schopnost rozeznat a poskytnout pracovní definice základních pojmů o životním prostředí, funkční, tj. širší porozumění přírodě a environmentálním interakcím a operacionalizovanou, zahrnující rovinu souvisejících dovedností, schopnost rozpoznat environmentální rizika, pracovat s informacemi, zaujímat stanoviska a promítat je do vlastního jednání. Podle Moseleyové (2000) pouze na této úrovni mohou být lidé chápáni jako skutečně environmentálně gramotní.

V roce 1977 pak byla na mezinárodní konferenci o environmentální výchově v Tbilisi přijata široce respektovaná definice, podle které je cílem environmentální výchovy: "posílit naše vědomí a porozumění ekonomické, sociální a ekologické provázanosti v městských i venkovských oblastech; poskytnout každému přiležitost dosáhnout znalostí, hodnot, názorů, odpovědnosti a dovedností $k$ ochraně a zlepšování životního prostředí a utvářet nové vzorce chování jednotlivců, skupin i společnosti jako celku vstř́cné k životnímu prostředí." (Tbilisi Declaration, 2005).

Z uvedených definic je zřejmé, že změna chování se jako cíl environmentální výchovy objevuje již od samého začátku. Všechny uvedené definice předpokládají, že by v rámci environmentální výchovy měly cílové skupiny získat takové znalosti, dovednosti, postoje či hodnoty, které je budou motivovat chovat se ohleduplně k životnímu prostředí a současně jim k takovému chování poskytnou potřebné know-how. 
Protože ale vědecká reflexe oboru se $v$ té době teprve rozvíjela, nebylo dlouho zjevné, jaké znalosti, dovednosti, postoje či hodnoty je relevantní k tomuto cíli rozvíjet. Pưvodní „naivní" teorie sedmdesátých let předpokládaly, že pokud budou lidé vědět více o životním prostředí, budou motivovanější k jeho ochraně a budou se proto chovat k životnímu prostředí ohleduplněji. Související teorie předpokládala lineární vazbu mezi znalostmi, postoji a chováním: nové znalosti povedou ke změně postojů, které vyústí do změny chování. Tyto teorie (tzv. KAB model) se ale nepodařilo experimentálně ověřit a jsou proto považovány za vyvrácené (Hungerford \& Volk, 1990).

V řadě zemí ale vědecká reflexe oboru neproběhla anebo nebyla praktickou komunitou akceptována. Ani ve Spojených státech, kde se teorie oboru rozvíjela nejrychleji, nebyla KAB teorie praxí opuštěna ještě na počátku 21. století (Hungerford, 2005).

Zde je užitečné zamyslet se nad faktory, které formují praxi environmentální výchovy. Je to jednak praxe samotná, kdy jednotliví učitelé či environmentální centra od sebe přebírají své praktiky, které mohou být více či méně efektivní. Za druhé je to stát, který svojí politikou vytváŕí určitý rámec pro environmentální výchovu. Za třetí je to vědecká komunita, která formuluje diskurs oboru a současně jej podrobuje kritické analýze. V zemích, kde vědecká komunita oboru nevznikla nebo byla suplována jinými obory (ekology, filozofy či oborově nezaměřenými pedagogy), se praxe nemohla plnohodnotně rozvinout. To je příklad i České republiky, jejíž hlavní kurikulární dokument pro základní vzdělávání definuje environmentální výchovu adekvátně stavu poznání oboru v sedmdesátých letech dvacátého století (Činčera, 2009).

Ve své předreflektivní fázi je environmentální výchova v podstatě libovolně interpretovatelná. Kdokoliv může vytvářet jakékoliv seznamy konceptů, postojů a dovedností a prezentovat je jako své či dokonce správné pojetí environmentální výchovy. Stejnou šíri můžeme najít na úrovni programů realizovaných praktickou komunitou. Česká střediska ekologické výchovy například často za environmentální výchovu označují programy o životě zvířat, botanice, alternativním životním stylu, lidových tradicích či programy výtvarně tvořivé a řemesla. Není přitom vysvětleno, jakým způsobem mohou takové programy motivovat či vést jejich účastníky k proenvironmentálnímu chování.

\section{Výstupově orientovaná environmentální výchova}

V roce 1980 zformulovali Hungerford, Peyton a Wilke (1980) na základě Tbiliské deklarace čtyři základní cílové úrovně environmentální výchovy (ekologické základy, pojmové porozumění - konflikty a hodnoty, výzkum a evaluace a environmentální akční dovednosti - trénink a aplikace). Těm předcházel nadřazený cíl, kterým je „pomoci občanům získat znalosti a především dovednosti související s životním prostředím a motivovat je k individuální či skupinové práci směřující k zachování dynamické rovnováhy mezi kvalitou života a kvalitou životního prostředí." Následně Hungerford a Peyton (1981 podle Marcinkowski, 2005) vymezili pět základních oblastí proenvironmentálního, resp. odpovědného environmentálního chování: ekomanagement, spotřebitelství, přesvědčování, právní a politické akce. Následující výzkumy zkoumaly vztahy mezi proměnnými operacionalizovanými na základě definovaných cílových úrovní a chováním.

Výzkumy vycházely z předpokladů, že: 1 . výchova by měla být vymezená cíli a výstupy, 2. odpovědné environmentální chování je hlavní cíl environmentální výchovy, 3. je možné na základě kvantitativních výzkumů identifikovat, jaké znalosti, dovednosti či postoje toto chování ovlivňují a 4. je možné experimentálně ověřit, jaké jsou efektivní strategie pro rozvíjení těchto oblastí.

Na základě řady dílčích výzkumů (Marcinkowski, 2005) byl v roce 1987 publikován Hinesův model (Hines et. al. 1986/7) zachycující klíčové proměnné vedoucí k proenvironmentálnímu chování, který posléze vedl k široce uznávanému modelu odpovědného environmentálního chování (REB) Hungerforda a Volkové (1990). Model zásadně ovlivnil environmentální výchovu v řadě ohledů. Lze říct, že jeho autoři sestavili 
nový paradigmatický model environmentální výchovy, obsahující doporučené strategie pro stavbu školního kurikula či modelů environmentální výchovy, evaluaci programů i výzkum vztahů mezi jednotlivými proměnnými. Model byl dále rozpracován řadou navazujících výzkumů, zaměěených např. na zdroje environmentální senzitivity (Chawla, 1998; 1999; Peterson, 2005; Sward \& Marcinkowski, 2005), strategie výuky environmentálních problémů a konfliktů (Ramsey, Hungerford \& Volk, 2005; Ramsey, 2005) či pro využití v oblasti environmentální interpretace (Knapp, Volk \& Hungerford, 1997).

$\mathrm{Na}$ základě modelu REB byly $v$ rámci Severoamerické asociace environmentální výchovy (NAAEE) vytvořeny metodické materiály pro výuku environmentální výchovy (Disinger, 1997), a doporučeny výstupy environmentální výchovy (NAAEE, 2004) i metodika pro environmentální programy nevládních organizací (Simmons, 2004). Z modelu vycházejí také nástroje připravené pro evaluaci školních kurikulí a programů environmentální výchovy (Marcinkowski, 1997).

Ve vztahu $\mathrm{k}$ tématu tohoto textu je třeba zmínit, že autoři modelu sice považují odpovědné environmentální chování za hlavní cíl („ultimate aim") environmentální výchovy, ale nikoliv za dílči očekávaný výstup konkrétního programu ("objective"). Odpovědné chování je tedy spiše určitým hlediskem, ze kterého má efektivní environmentální výchova vycházet a ke kterému mají konkrétní programy směřovat, nikoliv však tím, co by mělo být požadováno od žáků a promítáno do jejich hodnocení: "Žákům má být umožněno jednat a mohou dokonce $k$ jednání dostat potrebnou podporu, nikdy ale po nich nesmí být jednání vyžadováno (tj. ani v obecném smyslu ani v konkrétní situaci)." (Hungerford podle Marcinkowski, 1997). Model navíc výrazně podporuje rozvoj výzkumných a analytických dovedností, které mají žákům umožnit, aby samostatně prozkoumávali vybrané environmentální konflikty $^{1}$, analyzovali úhly pohledu jednotlivých zainteresovaných stran, zaujali vlastní stanovisko a na jeho základě navrhli postup řešení (NAAEE, 2004). Podstatou modelu tedy není nutit žáky ke konkrétnímu chování (např. kupovat biopotraviny), ale rozvinout $u$ nich předpoklady $k$ tomu, aby se o možnosti odpovědného chování v daném kontextu sami aktivně zajímali a pak jednali tak, jak to $\checkmark$ dané situaci vyhodnotí jako nejlepší možnost. ${ }^{2}$

Současně nelze říct, že by model byl celosvětově akceptován. Jak bylo uvedeno, $\checkmark$ řadě regionů neproběhla $z$ různých důvodů vědecká reflexe oboru a model se proto nedostal do povědomí profesní komunity. $\vee 70$. a 80 . letech 20 . století vznikly další alternativní př́stupy, které čerpaly z jiných myšlenkových tradic. Př́kladem byla hlubinná ekologie (Seed a kol., 1993), která čerpala z filozofických a mystických tradic či globální výchova (Pike \& Selby, 1994), kteří zahrnuli environmentální výchovu do širšího rámce

\footnotetext{
1 V rámci modelu je rozlišováno mezi environmentálními problémy (problems) a konflikty (issues). Jako "environmentální problémy" se zde chápou objektivně existující problémy životního prostředí, které mohou, ale nemusí být způsobeny lidskou činností. Environmentální konflikty označují společenskou diskusi o řešení problémů. Konflikty vznikají ze střetu různých názorů a jejich hodnotových východisek na řešení daného problému.

2 Je třeba zmínit, že v řadě publikací je chování žáků zařazeno mezi "goals" i „objectives" programu. Např. Bennett (1984) uvádí ve své evaluační metodice řadu modelových výstupů na úrovni chování žáků, stejně tak Sellersová (2007). Zde je třeba si uvědomit rozdíl mezi tím, zda hodnotíme žáka nebo program. Zatímco u žáků je možné hodnotit míru jejich znalostí či dovedností, ale nikoliv jaké zastávají postoje nebo jak se ve vztahu k životnímu prostředí chovají, je měření změn v žákovských postojích a chování relevantním indikátorem efektivity programu. Efektivita programu zaměřeného na biopotraviny tak může být např́klad hodnocena podle toho, do jaké míry se zvýši počet biopotravin koupených žáky po programu ve srovnání se stavem před programem. Od samotných žáků ale může být vyžadováno pouze osvojení určitých znalostí a dovedností (tj. např. to, zda poznají příslušnou ekoznačku nebo zda vyhodnotí výhody a nevýhody biopotravin), ale nikoliv to, zda si biopotraviny opravdu koupí - to zůstává vždy jejich svobodným rozhodnutím. Tento přístup proto nelze podle mého názoru považovat za behaviorální manipulaci. Je ale zřejmé, že zůstává snaha připravit programy co nejlépe tak, aby změnily chování co největšího počtu svých absolventů žádoucím směrem.
} 
alternativního pedagogického hnutí. Jinou alternativou byla výchova o Zemi, která vznikla v prostředí profesní environmentálně výchovné komunity, se kterou se ale kriticky rozešla (Matre, 1999). V České republice po roce 1989 vědecká komunita v oboru neexistovala a nově vznikající komunita praktiků přijímala především metody a aktivity od partnerských profesních komunit ze zahraničí.

\section{Kritika výstupově orientované environmentální výchovy}

Souběžně s rozvojem a širokou aplikací REB modelu se $v$ devadesátých letech objevují a šiŕí také alternativní přístupy, které jej přímo či nepřímo kritizují. Přestože hlubinná ekologie se stává spíše marginálním proudem, některé její myšlenky ožívají v hnutí výchovy k ekogramotnosti (Stone \& Barlow, 2005) či v lokální výchově (placebased education) (Sobel, 2005). Souběžně se rozvíjí i globální výchova, která posiluje svưj zájem o environmentální tématiku (Selby, 2000). V rámci hnutí výchovy o Zemi vzniká vlastní výzkumné centrum, jsou publikovány nové programy, které jsou efektivně realizovány v řadě zemí, např. v Číně (Yan \& Johnson, 2008). Po konferenci OSN v Rio de Janeiro (1992) začaly mezinárodní organizace a vlády prosazovat koncepci výchovy k udržitelnému rozvoji, která měla zabezpečit splnění mezinárodních závazků jednotlivých zemí. Koncept výchovy splňující tuto „politickou objednávku" byl některými teoretiky odmítnut jako nepř́ipustná ideologická deformace výchovy (McClaren, 1993), jinými naopak přijat jako vyjádření nového paradigmatického rámce environmentální výchovy (Östman \& Öhman, 2007) a dalšími považován za redundantní (Robottom, 2007).

Z prostředí vědecké komunity pak vzešla kritika dominantní kvantitativní metodiky, ve které Robottom a Hart (podle Smith-Sebasto, 2005) našli behaviorální tendence. Začal se prosazovat kvalitativní výzkum a analýza environmentální výchovy ze sociálně kritického hlediska, tj. jako praxe, která může omezovat, ale i udržovat rưzné formy environmentálně - sociálního útlaku a nespravedlnosti (podle Smith-Sebasto, 2005).

Určitým katalyzátorem rozporů mezi dominantním REB paradigmatem a nově formulovanými př́stupy se stal článek Walse a van der Leije $v$ Canadian Journal of Environmental Education (1997). Autoři $\vee$ něm podrobili tvrdé kritice tehdejší práci na přípravě standardů environmentální výchovy NAAEE. Podle jejich názoru je REB model, ze kterého NAAEE vycházela, projevem pozitivistického a behaviorálního př́stupu, který je kořenem současné environmentální krize. Hrozí, že studenti a učitelé budou manipulováni výzkumníky, kteří je budou řídit podle svých teorií. Podle jejich názoru nemá environmentální výchova usilovat o změnu chování jednotlivců, ale o reformování celé společnosti "chování jednotlivců není klíčovým faktorem řešení problémů, environmentální konflikty jsou ř́zeny politickými silami a proto je účinnější kolektivní akce". Oproti př́stupu, který autoři označují jako behaviorální, staví nebehaviorální pojetí environmentální výchovy, která není založena na výstupech, ale na procesech. Podle jejich názoru by environmentální výchova neměla vycházet $z$ otázky, co by žáci měli znát a umět, ale jaké by měly být optimální podmínky pro zajištění její kvality. Ty vymezují pomocí čtyř kritérií a čtyř dimenzí. Environmentální výchova by měla být blízko běžnému životu, tj. vycházet např. z bezprostřední zkušenosti žáků. Měla by být kognitivně podnětná, tj. měla by např. využívat učení samostatným objevováním. Měla by být kontroverzní, tj. měla by stimulovat diskusi a měla by být zaměřená na konkrétní pozorování, akční kompetence a komplexní studium konfliktu. Proces učení by měl obsahovat čtyři hlavní dimenze: konstruktivní, ve které žáci konstruují nové poznání, kritickou, ve které analyzují hodnoty své i ostatních, emancipační, ve které analyzují a nahrazují stávající mocenská omezení komunikace a transformační, ve které aktivně ovlivňují svět kolem sebe.

Text vyvolal řadu kritických odezev. Podle McClarena (1997) a Rotha (1997) článek neúnosně zjednodušuje situaci v oboru tím, že jej dichotomicky rozděluje na behaviorální a nebehaviorální př́stupy. V rámci oboru existuje celá řada rưzných směrů, které často kombinují oba přístupy. Podle McClarena (1997) navíc autoři nesprávně používají pojem „behaviorální". Ve skutečnosti není behaviorální pedagogika pro environmentální výchovu vůbec typická. Podstatou sporu není podle něj behaviorálnost či nebehaviorálnost př́stupu, 
ale spíše rozpor mezi výstupově (outcome-based) a procesně (process-based) orientovanou výchovou. Ramsey (2005) upozorňuje na desinterpretaci Hungerfordova et. al. modelu. Jak již bylo uvedeno, model je sice veden snahou ovlivnit občanské chování žáků, obsahuje ale výrazné pojistky proti indoktrinaci. Žáci jsou především vedeni k samostatné analýze konfliktů a zaujímání vlastního stanoviska, v neposlední řadě i k vlastnímu rozhodnutí o přijetí či nepřijetí určité akce. Roth (1997) i McClaren (1997) dále kritizují to, že Wals a van der Leij odmítají přijmout proenvironmentální chování (resp. kvalitu života) jako cíl výchovy. Podle McClarena (1997) každá výchova ovlivňuje chování, což platí i pro (autory) prosazované kritické myšlení. Kritéria procesně orientované výchovy navržená oběma autory jsou podle Rotha (1997) již ve stávajícím modelu obsažena a nepřinášejí nic nového. Konečně Ramsey (2005) upozorňuje, že procesně orientované modely kladou extrémně vysoké nároky na odborné kvality učitele, který musí být schopen facilitovat proces výuky, ve kterém žáci sami navrhují cíle, zkoumají problémy a potřebné znalosti a dovednosti získávají v rámci vlastní práce. Paradoxně podle něj taková výuka znamená ve srovnání s výstupově orientovaným kurikulem vyšší riziko potenciální manipulace učitelem.

\section{Procesně orientovaná environmentální výchova}

V posledních deseti letech se zdá, že se procesně orientovaná environmentální výchova stala legitimní alternativou. Současně ve výzkumné sféře došlo k určitému posunu směrem ke kvalitativní metodice, zatímco původní čistě kvantitativní přístup je chápán jako ne zcela dostačující (Palmer, 2003). Metodiky pro evaluace programů začaly zdůrazňovat sílu kvalitativních nástrojů umožňujících interpretaci prožíání programu účastníky a doporučují zpravidla smíšené modely evaluace (Frechtling, 2002; Simmons, 2008). Vynořilo se několik nových přístupů, které ve větší či menší míře uplatňují principy procesně orientované výchovy.

Tyto alternativní přístupy zpravidla uplatňují některé z následujících přístupů. Nezdůrazňují nebo odmítají odpovědné chování jako hlavní cíl environmentální výchovy, raději hovoří o ekogramotnosti, moudrosti a vyzrálosti žáka. Zpravidla nevymezují konkrétní očekávané výstupy programů, raději pracují s obecněji vymezenými kompetencemi či klíčovými tématy (např. smysl pro úžas, smysl pro místo atd.). Podle nich jsou pak připravovány programy, ve kterých ke tvorbě nových znalostí, změně postojů či rozvoji dovedností dochází jakoby neplánovaně. Zdůrazňují participativní úlohu žáka jako tvưrce nového poznání, žáci se mají podílet na určování cílư i obsahu kurikula, učitel je spíše facilitátorem procesu. Při evaluaci upřednostňují kvalitativní nebo smíšené metody.

Tímto směrem jde například hnutí výchovy k ekogramotnosti, spojované s Davidem Orrem, Zenobií Barlow, Fritjofem Caprou a dalšími autory. Hnutí se soustředí především na environmentální dimenzi provozu školy (řada projektů podporovaných centrem se soustředí na ekologizaci školních jídelen a jejich propojením s místními producenty), vztah k regionu a osvojení základních ekologických kompetencí na praktických př́kladech (Stone \& Barlow, 2005). S hnutím korespondují i myšlenky Stephena Sterlinga (2001) na posun od výchovy o udržitelnosti a výchovy pro udržitelnost k udržitelné výchově (education as sustainability). K hnutí má blízko také lokální (place-based) výchova Davida Sobela (2005) prosazujícího bioregionalismus jako výchozí bod environmentální výchovy.

Jiným směrem jde např́klad Palmerová (2003), která navrhuje jako zastřešující rámec pro všechny př́stupy $v$ environmentální výchově Integrovaný model pro strukturování environmentální výchovy, vycházející z rozdělení výchovy na „v přírodě", "o př́rodě" a „pro př́rodu". Model neobsahuje přehled specifických kompetencí a pouze předpokládá, že kvalitní environmentální výchova bude obsahovat všechny uvedené dimenze.

V Evropě je důležitým centrem procesně orientované environmentální výchovy Univerzita v Aarhusu (Dánsko). Mogensen, Breiting, Östman a další navrhují postavit environmentální výchovu na rozvoji kritického myšlení jako předpokladu osvojení akčních 
kompetencí. Environmentální výchova vychází v jejich pojetí primárně ze společenských věd, problémy životního prostredí jsou chápány jako konflikty názorů na využití území (Mogensen, 1997; Breiting et. al., 1999; Mogensen \& Mayer, 2005).

Breiting et. al. (1999) se ostře vymezuje proti Hungerfordově REB modelu. Podle něj leží zásadní rozdíl $v$ tom, zda má být cílem environmentální výchovy přímo ovlivňovat chování cílové skupiny nebo rozvíjet její akční kompetence bez směřování ke konkrétnímu chování: „Kritérium úspěchu je, pokud studenti končí jako zralí, samostatní lidé, kteří jsou schopni kriticky myslet a stávají se odpovědnými jedinci a kvalifikovanými účastníky demokratických procesů." (s. 57)

K procesně orientovaným modelům se hlásí i Dlouhá (2009a). Podle jejího přístupu jsou cílem vzdělávání subjektivně oceňované kvality, které se vynořují v průběhu výchovně vzdělávacího procesu. Kvalitami pak jsou určité schopnosti či dispozice jednotlivce, které mají nadčasový charakter. Chování pak je spíše indikátorem kvality než výchovným cílem.

Autorka dále svůj koncept propojuje s konceptem kompetencí, které chápe jako typ vzdělávacích kvalit. Kompetence charakterizuje s odkazy na další zdroje jako určité proaktivní kvality či dispozice jedince, vždy vztažené k určitému jednání a výsledku. Prezentuje různé přístupy $\mathrm{k}$ formulaci klíčových kompetencí environmentální výchovy a propojuje koncept s paradigmatem výstupově orientované výchovy (Dlouhá, 2009b).

\section{Diskuse}

Je otázkou, zda argumenty, které se objevily po publikování Walsova a van der Leijova článku (1997) neplatí i pro další alternativní př́stupy. Pokud se nedopustíme desinterpretace Hungerfordova modelu (1990), je těžké najít větší rozdíl mezi konceptem odpovědného občana kriticky zvažujícího svá rozhodnutí v environmentálním kontextu a Bretingovým (1999) kvalifikovaným účastníkem rozhodovacích procesů. Viditelný rozdíl vidím pouze $v$ tom, že REB model předpokládá rozvinutí určitých vstupních proměnných (např. ekologické principy) před analýzou environmentálních konfliktů a klade větší dưraz na ř́zený rozvoj výzkumných dovedností žáků. Je možné, že REB model v důsledku těchto rozdílů více motivuje $\mathrm{k}$ zaujetí proenvironmentálních postojů a zvyšuje $\mathrm{v}$ daném kontextu pravděpodobnost volby proenvironmentálního rozhodnutí. Takové tvrzení by ale bylo třeba výzkumně ověřit.

Stejně tak nenacházím zásadní rozpor REB modelu se Sobelovým (2005), Caprovým (Stone \& Barlow, 2005) či Sterlingovým (2001) pojetím. Rozdíly Ize najít spíše v síle akcentu na jednotlivé oblasti definované REB modelem a preferované strategie jejich rozvíjení. Ty na rozdíl od REB modelu předpokládají větší míru samostatnosti žákủ ve všech fázích vyučovacího procesu, větší propojení s místní sociální problematikou, prípadně kladou silný akcent na ekologizaci provozu školy. Jde také o strategie kladoucí větší nároky na pedagogy i žáky.

Integrovaný model Palmerové (2003) a další související přístupy neuvádějící žádné kompetence a definující environmentální výchovu pouze z hlediska vágních oblastí a dimenzí považuji za krok zpět směrem k období nevyjasněných hranic oboru.

Přestože jsou nové alternativní př́stupy $v$ environmentální výchově často prezentovány jako nová generace environmentální výchovy (Östman \& Öhman, 2007) a jejich odlišnosti od "tradičních" př́stupů jsou zvýrazňovány různými srovnávacími tabulkami (Breiting et. al., 1999; Wals \& van der Leij, 1997; Sterling, 2001), nezdá se, že by představovaly dramaticky odlišnou alternativu. I když v praxi hraje roli, zda pedagog vytváŕi svůj program podle procesně či výstupově orientované metodiky, zdají se být prezentované př́stupy spíše než na opačných pólech procesně /výstupové škály seřazeny po obou stranách jejího středu. Škála procesní/výstupové orientace navíc patrně není dostačujícím měřítkem pro klasifikaci existujících př́stupů. Je možné, že jejich komplexitu by bylo potřeba popsat pomocí kombinace škál, zahrnující např́klad osu 
logocentrický/pedocentrický přístup, společenskovědní orientace/přírodovědná orientace a další. Navíc Ize připustit, že v rámci jednoho př́stupu jsou uplatňovány postupy typicky procesní i výstupové, logocentrické i pedocentrické atd.

Pro rozvoj environmentální výchovy je tedy vhodnější, spíše než vytvářet vyhraněné klasifikace, podporovat diverzitu přístupů a hledat cesty k jejich adekvátní vědecké reflexi i praktické aplikaci v místním kontextu.

Odmítnout proenvironmentální chování jako hlavní cíl environmentální výchovy považuji za odmítnutí smyslu environmentální výchovy a možná i výchovy jako takové. Je otázkou, zda lze výchovu vůbec uvažovat bez vztahu k aplikaci: učíme se číst a psát nikoliv pro získání obecné kvality, ale proto, abychom četli a psali. Učíme se znát dějiny nebo rozumět filozofickým myšlenkám proto, abychom volili moudrá, poučená a odpovědná rozhodnutí. Stejně tak rozvíjíme environmentální senzitivitu, výzkumné dovednosti či akční kompetence dětí nikoliv jako univerzální kvality nesouvisející s jejich praktickým životem, ale proto, aby se $v$ něm moudře a odpovědně rozhodovali a do svých rozhodnutí zahrnovali také environmentální perspektivu.

Je možné, že klíčovou otázkou celé diskuse je, zda (či do jaké míry) v pedagogické praxi využívat existující poznatky o proměnných ovlivňujících environmentální chování, nebo zda je odmítnout jako skrytou manipulaci a aplikovat čistě procesní metodiky otevírající volný prostor žákům. Je ale také zřejmé, jaká otázka následuje: budeme spokojeni, pokud naše programy nebudou mít na chování cílové skupiny žádný (nebo budou mít záporný) vliv? Není naší povinností využít veškeré existující poznatky pro zajištění maximálního efektu programu? Osobně se domnívám, že při zachování naprostého respektu k osobnosti účastníků programu a jejich svobodnému rozhodování je odpovědné chování to, k čemu programy musí směřovat a byla by chyba nepracovat $\mathrm{s}$ tím, co je známé a k dispozici. Nezbytností je pocit hluboké pokory a odpovědnosti, kterou by měl cítit každý, kdo se výchovou v jakékoliv oblasti zabývá.

Procesně orientované přístupy přinesly environmentální výchově potřebnou kritiku a nové impulzy. Považuji za velice důležité nespokojovat se s jedinou teorií a hledat alternativní cesty. Současně ale věřím, že dobrá teorie musí být ověřena praxí. V kontextu environmentální výchovy to znamená realizovat na základě alternativních př́stupů konkrétní programy a ty pak vyhodnotit s použitím vhodné evaluační metodiky. Evaluace by pak měla přinést odpovědi na efektivitu nového přístupu, př́padně vymezení jejích podmínek. Kromě hodnocení vlivu programu na nové znalosti, postoje, hodnoty a dovednosti účastníků by pak měla sledovat i jeho vliv na nové vzorce chování.

\section{Literatura}

- Bennett, D. B. (1989). Evaluating Environmental Education in Schools. A practical guide for teachers. : UNESCO - UNEP, Division of Science, Technical and Environmental Education. Retrieved from http://unesdoc.unesco.org/images/0006/000661/066120eo.pdf

- Breiting, S., Hedegaard, K., Mogensen, F., Nielsen, K., \& Schnack, K. (2009). Action Competence, Conflicting interests and Environmental Education. Copenhagen: Aarhus University. Retrieved from http://www.MUVIN.net

- Činčera, J. (2009). Analýza průřezového tématu Environmentální výchova v Rámcovém vzdělávacím programu pro základní vzdělávání. Envigogika, 4(1), Retrieved from http://www.envigogika.cuni.cz/index.php/Envigogika/article/view/33 http://dx.doi.org/10.14712/18023061.33

- Disinger, J. F. (1997) Environment in the K-12 Curriculum: An Overview. In R. J. Wilke (Ed.), Environmental Education. Teacher Ressource Handbook. A Practical Guide for K-12 Environmental Education (pp. 23-44). Thousand Oaks: Corwin. 
- Disinger, J. F. (2005) Environmental Education's Definitional Problem. In H. H. Hungerford, W. J. Bluhm, T. L. Volk, \& J. M. Ramsey (Eds.), Essential Readings in Environmental Education (pp. 17-32). Champaign: Stipes.

- Dlouhá, J. (2009). Kompetence v environmentálním vzdělání. Envigogika, 4(1), Retrieved from http://www.envigogika.cuni.cz/index.php/Envigogika/article/view/34

- Excellence in Environmental Education - Guidelines for Learning (Pre K-12) (2004). Rock Spring, GA: North American Association for Environmental Education. Retrieved from http://www.naaee.org/npeee/learner guidelines.php

- FRECHTLING, Joy et. al, . The 2002 User-Friendly Handbook for Project Evaluation. : The National Science Foundation. Retrieved http://www.nsf.gov/pubs/2002/nsf02057/nsf02057.pdf

- Hungerford, H. R. (2005) The Myth of Environmental Education - Revisited. In H. H. Hungerford, W. J. Bluhm, T. L. Volk, \& J. M. Ramsey (Eds.), Essential Readings in Environmental Education (pp. 49-56). Champaign: Stipes.

- Hungerford, H., Peyton, B. R., \& Wilke, R. J. (1980). Goals for Curriculum Development in Environmental Education. The Journal of Environmental Education,11(3), 42-47.

- Chawla, L. (1999). . Life Paths Into Effective Environmental Education, 31(1), 15-26. Retrieved from http://www.tandfonline.com/doi/abs/10.1080/00958969909598628 http://dx.doi.org/10.1080/00958969909598628

- Chawla, L. (1998). Significant Life Experiences Revisited: A Review of Research on Sources of Environmental Sensitivity. The Journal of Environmental Education, 29(3), 11-21.

- Kahn, R. (2007). Towards Ecopedagogy. Weaving a Broad-based Pedagogy of Liberation for Animals, Nature and the Opressed People of the Earth. : University of North Dakota.

- Knapp, D., Volk, T. L., \& Hungerford, H. R. (1997). ., 28(3), 24-34. Retrieved from http://www.tandfonline.com/doi/abs/10.1080/00958964.1997.9942826 http://dx.doi.org/10.1080/00958964.1997.9942826

- Marcinkowski, T. (1997) Assessment in Environmental Education. In R. J. Wilke (Ed.), Environmental Education. Teacher Ressource Handbook. A Practical Guide for K-12 Environmental Education (pp. 143-198). Thousand Oaks: Corwin.

- Marcinkowski, T. (2005) Predictors of Responsible Environemental Behavior. A Review of Three Disertation Studies. In H. H. Hungerford, W. J. Bluhm, T. L. Volk, \& J. M. Ramsey (Eds.), Essential Readings in Environmental Education (pp. 265-294). Champaign: Stipes.

- Matre, S. v. (1999). Earth Education .. a new beginning. Greenville: The Institut for Earth Education.

- McClaren, M. (1993). Green Teacher. Education for Planet Earth. Education, not ideology, 35, 17-18.

- McCLAREN, M. (1997). Reflections on "Alternatives to National Standards in Environmental Education: Process-Based Quality Assessment". Canadian Journal of Environmental Education, 2, Retrieved from http://www.uleth.ca/edu/research/ictrd/cjee/volume 2/mcclaren.html

- Mogensen, F. (1997). Critical thinking: a central element in developing action competence in health and environmental education. Health Education Research. Theory \& Practice. 1997, Vol. 12, n. 4, p. 429-436. Health Education Research. Theory \&amp; Practice, 12(4), 429436. Retrieved from http://her.oxfordjournals.org/cgi/doi/10.1093/her/12.4.429 http://dx.doi.org/10.1093/her/12.4.429

- Mogensen, F., \& Mayer, M. (2005) Eco-school. Trends and Divergences. A Comparative study of ECO-school development process in 13 countries. InVienna. : Austrian Federal Ministry of Education. Retrieved from http://www.ubu10.dk/downloadfiles/Comparative2.pdf 
- Morrone, M., Mancl, K., \& Carr, K. (2001). Development of a metric to test group differences in ecological knowledge as one component of environmental literacy. The Journal of Environmental Education, 32(10), 95-896.

- Moseley, C. (2000). Teaching for environmental literacy. The Clearing House, 74(1), 23-24.

- Negev, M., Sagy, G., Garb, Y., Salzberg, A., \& Tal, A. (2008). Evaluation the Environmental Literady of Izraeli Elementary and High School Students. The Journal of Environmental Education, 38(2), 3-20.

- Östman, L., \& Öhman, J. (2007). Selective traditions within Environmental Education. Durban: WEEC.

- Palmer, J. A. (2003). Environmental education in the 21st Century. London; New York.

- Peterson, N. (2005) Factors Influencing the Development of Environmental Sensitivity. In H. H. Hungerford, W. J. Bluhm, T. L. Volk, \& J. M. Ramsey (Eds.), Essential Readings in Environmental Education (pp. 295-300). Champaign: Stipes.

- Palmer, J. A. (2003). Environmental education in the 21st Century. London; New York.

- $\quad$ Pike, G., \& Selby, D. (1994). Globální výchova. Praha: Grada.

- Ramsey, J. M., Hungerford, H. H., \& Volk, T. L. A Technique for Analyzing Environmental Issues. In H. H. Hungerford, W. J. Bluhm, T. L. Volk, \& J. M. Ramsey (Eds.), Essential Readings in Environmental Education (pp. 191-196). Champaign: Stipes.

- Ramsey, J. (2005) Comparing Four Environmental Problem Solving Models: Additional Comments. In H. H. Hungerford, W. J. Bluhm, T. L. Volk, \& J. M. Ramsey (Eds.), Essential Readings in Environmental Education (pp. 161-172). Champaign: Stipes.

- Robottom, I. (2007). Re-badbed Environmental Education: Is ESD more than just a slogan?. Southern African Journal of Environmental Education, 40, 90-96.

- Roth, R. E. (1997). A Critique of "Alternatives to National Standards in Environmental Education: Process-Based Quality "Assessment". Canadian Journal of Environmental Education, 2, Retrieved from http://www.uleth.ca/edu/research/ictrd/cjee/volume 2/roth.htm

- SEED, John a kol, (1993). Myslet jako hora. Shromáždění všech bytostí. Prešov: Nadácia Zelená nádej.

- Sellers, J. . MEERA Evaluation Glossary. : University of Michigan. Retrieved from http://meera.snre.umich.edu

- Selby, D. (2000). A darker shade of green: The importance of ecological thinking in global education and school reform. Theory into Practice, 39(2), 88-96.

- $\quad$ SIMMONS, Bora et. al, (2004). Nonformal Environmental Education Programs: Guidelines for Excellence. : North American Association for Environmental Education. Retrieved from http://naaee.org/npeee/nonformal/nonformalguidelines.pdf

- Simmons, B. . Designing Evaluation for Education Projects. : Office of Education and Sustainable $\quad$ Development. Retrieved from http://wateroutreach.uwex.edu/use/documents/NOAAEvalmanualFINAL.pdf

- Stephen, S. . Sustainable education. Re-visioning Learning and Change. Bristol: Green Books; The Schumacher Society.

- $\quad$ SMITH-Sebasto, N. J. (2005) The Pros and Cons of Research in Environmental Education. In H. H. Hungerford, W. J. Bluhm, T. L. Volk, \& J. M. Ramsey (Eds.), Essential Readings in Environmental Education (pp. 329-348). Champaign: Stipes. 
- Sobel, D. (2005). Place-Based Education: Connecting Classrooms \& Communities. Barrington: The Orion Society.

- $\quad$ STAPP, William B. et. al, The Concept of Environmental Education. In H. H. Hungerford, W. J. Bluhm, T. L. Volk, \& J. M. Ramsey (Eds.), Essential Readings in Environmental Education (pp. 33-36). Champaign: Stipes.

- STONE Michael K, , \& Barlow, Z. (2005). Ecological Literacy. Educating Our Children for a Sustainable World. San Franciso: Sierra Club Books.

- Sward, L. L., \& Marcinkowski, T. (1998) Environmental Sensitivity: A Review of the Research, 1980-1998. In W. J. Bluhm, T. L. Volk, \& J. M. Ramsey (Eds.), Essential Readings in Environmental Education (pp. 301-312). Champaign: Stipes.

- Essential Readings in Environmental Education The Tbilisi Declaration. Intergovernmental Conference on Environmental Education. In H. H. Hungerford, W. J. Bluhm, T. L. Volk, \& J. M. Ramsey (Eds.), (pp. 13-16). Champaign: Stipes.

- Vadala, C. E., Bixler, R. D., \& JAMES, J. Joy, (2007). Childhood Play and Environmental Interest: Panacea of Snake Oil?. The Journal of Environmental Education, 39(1), 3-18. Retrieved from http://www.tandfonline.com/doi/abs/10.3200/JOEE.39.1.3-18 http://dx.doi.org/10.3200/JOEE.39.1.3-18

- Wals, A. E. J., \& Leij, T. v. d. (1997). Alternatives to National Standards in Environmental Education: Process-Based Quality Assessment. Canadian Journal of Environmental Education. 1997, 2, Retrieved from http://www.uleth.ca/edu/research/ictrd/cjee/volume 2/Arjen.htm

- Wals, A. E. J., \& Leij, T. v. d. (1997). Alternatives to National Standards for Environmental Education: A Response to Roth and McClaren. Canadian Journal of Environmental Education. 1997, 2, Retrieved from http://www.uleth.ca/edu/research/ictrd/cjee/volume 2/wals.htm

- Yan, B., \& Johnson, B. (2008) Curriculum integration through environmental learning. A case study. In Paper presented at the North American Assocication for Environmental Education Research Symposium, Wichita, KS. Wichita, KS. 
Časopis Envigogika vydává Centrum pro otázky životního prostředí UK. Vývoj časopisu je podpořen projektem OP VK Mezioborová sít udržitelného rozvoje.

Více najdete na internetových stránkách projektu mosur.czp.cuni.cz
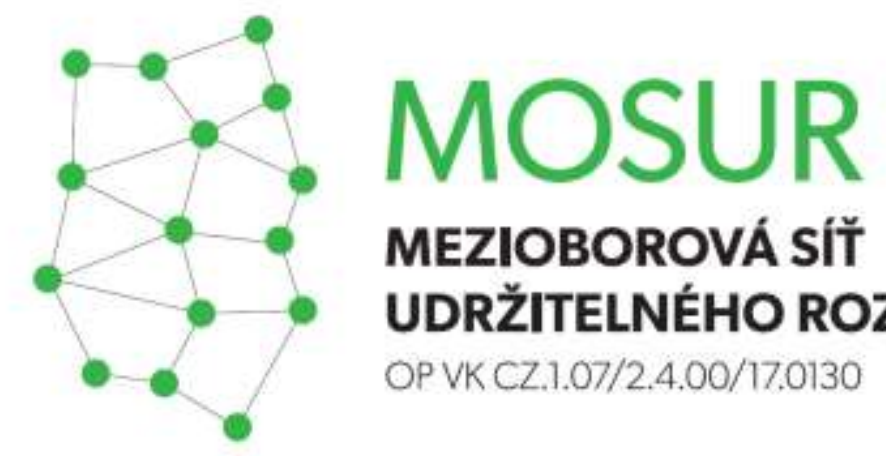

\section{MEZIOBOROVÁ SÍT} UDRŽITELNÉHO ROZVOJE

OP VK CZ.1.07/2.4.00/17.0130
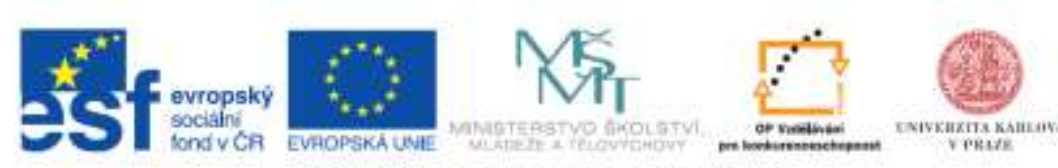

INVESTICE DO ROZVOUE VZDELAVANI 